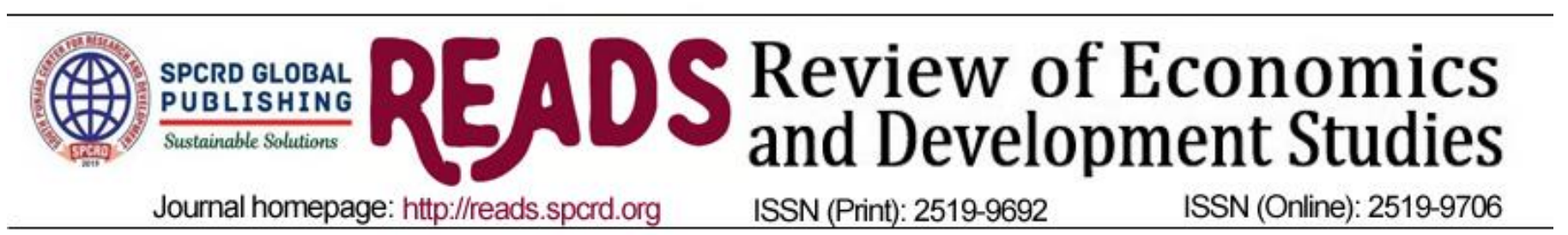

\title{
Pakistan-United States Relations in Trump Era and FATF
}

\author{
a Saadat Hassan, ${ }^{\text {b }}$ Shahid Hussain Bukhari \\ ${ }^{a}$ PhD Scholar school of Politics \& International Relations, Quaid-i-Azam University Islamabad, Pakistan \\ ${ }^{\mathrm{b}}$ Associate Professor, Department of International Relations, Bahauddin Zakariya University, Multan, Pakistan
}

\begin{tabular}{l}
\hline ARTICLE DETAILS \\
History: \\
Accepted 16 March 2020 \\
Available Online 31 March 2020
\end{tabular}

Keywords:

FATF, Pak-US, US Withdrawal,

Afghanistan, Taliban Peace

Process

JEL Classification:

D70, D72, D79

DOI: $10.47067 /$ reads.v6i1.189

\begin{abstract}
The Financial Action Task Force (FATF) has become a modern diplomatic instrument for the United States of America to use it the way it wants for. As the U.S. led Afghan peace process embraced the victory, Washington, Afghan Taliban and Kabul government have agreed upon limited ceasefire and withdrawal of troops from Afghanistan soil. Pakistani authorities are equally ready to cease the movement, amid the challenges posed by the FATF, by facilitating U.S.-Taliban peace deal in Qatar on Feb 29, 2020, the biggest development happened ever in South Asian region. It happened for the first time of grinding warfare since the U.S. invasion in 2001 which is considered to be a vital step to end the insurgency altogether in the region. Pentagon finally accepted Islamabad's stance that there is no military solution to the Afghan imbroglio. Pakistani authorities, through Afghan authorities, are said to be taking over Pakistani Taliban purportedly operating from Afghanistan. After playing a key role in brokering the said peace deal, the challenge of FATF as a diplomatic tool to pile up pressure on Islamabad to mold its role in favour of the US and the Taliban talks.
\end{abstract}

(C) 2020 The authors. Published by SPCRD Global Publishing. This is an open access article under the Creative Commons Attribution-

NonCommercial 4.0

Corresponding author's email address: shahidbukhari@bzu.edu.pk

\section{Introduction}

The application of FATF terms and conditions on Pakistan apparently pave the way for these successful deal since Islamabad not only facilitated the peace talks but also persuaded the Taliban to show flexibility on an intra-Afghan dialogue. So, it is noteworthy to work on what was the outcome of US-led peace process and its reflection in the relation of FATF's conditions vis-a-vis Pakistan. The research would go on with future perspective of the U.S. overseeing Afghanistan-Pakistan talks about mutual security concerns. Pak-US future relationships after U.S. and international troops withdrawal started and Washington would seek endorsement of Taliban agreement from the UN Security Council (Kaura \& Era, 2017). Research design implies a research blueprint or strategy to know about foreign policy trends vis-a-vis Pakistan and America. The prediction, strategy and trends i.e., hypothesis was also applied. It lays down a clear roadmap for generation, collection, evaluation and quantification of data. The research evaluated different books and research journals to build the opinion of diplomats, researchers, professors and thinkers. As far as sources are concerned, this paper relied on secondary 
sources, such as books, research journals, interviews, newspapers articles however primary source was also somehow consulted for measurement of the main argument of the study such as documents analysis and study of foreign policy books.

Qualitative methods effectively deal with discovery of social reality, its rich description, meaning and interpretation. Objective of this paper is many folds but mainly it focusses upon the core issue of Pakistan response and impact of FATF as a challenge for Pakistan vis-a-visa Pak-U.S. ties and Reasons for Pakistan being in FATF Grey List. Conducting this study on empirical basis I tested this hypothesis FATF Challenge: A Case Study of Pak-U.S. Ties. This is an analytical study in historical and contemporary perspective. The literature review for this research study is based on scholarly papers, research journals, special reports, articles and other sources relevant to the subject of the research too. Both primary and secondary sources are used to undertake the research to evaluate the hypothesis and answer these questions,

- What is FATF \& how it is employed as a foreign policy tool in international system?

- Why is Pakistan in FATF's grey list and did FATF serve the U.S. foreign policy agenda vis-a-vis Pakistan?

As American interests continued to prevail in South and Central Asian region by pouring pressure on Pakistan through sword of FATF by placing her on its international terror-financing watch list. The Paris-based monitoring group to tackle terrorism financing continued to alert Islamabad either to blacklist it at a time when Pakistani authorities were facilitating all stakeholders to get a peaceful and equally respectful withdrawal from Afghanistan after fighting a long war which brought nothing, except the destruction, uncertainty and chaos in the region. The issue of terror financing, ranging from Afghan Taliban, their other proxies, the Haqqani Network and Tehreek-e-Taliban Pakistan (TTP), has been one of the key factors which put the region in trouble since the Soviet Union's invasion in Afghanistan's affairs four decades ago. The U.S. authorities and international community has been blaming Pakistan of supporting militants. Even President Donald Trump once said Pakistan continued to sponsor militant groups, the statement inflamed an already tense relationship when he tweeted about decades of U.S. aid to Pakistan with "nothing but lies and deceit" in return. Then FATF's challenge created financial problems, foreign investments in particular, for Pakistan. (Yusuf, 2017).

\section{Pakistan-United States Relations in Trump Era}

The future of Pak-US ties is very much up hanging in the balance. Many opinion makers believe that Islamabad and Washington relations will depend on successful Afghan peace process. If peace and reconciliation efforts move forward, according to many experts that the both allies would get some degree of success and somehow, they achieved reasonable success story and from here Washington and Islamabad relationship could score a major victory (Trump, 2017). But if the execution of talks between Afghan government and Afghan Taliban do not remain successful, and especially if Islamabad is seen by the U.S. as being somehow responsible for that, then the relationship could suffer. At this moment in time, the Trump administration has been very up front and clear about its expectations for the relationship in the near future: It will center the relationship around peace and reconciliation in Afghanistan and counterterrorism in Pakistan, but if the U.S. sees Pakistan making progress on both of those fronts, there could be great potential to broader the relationship into the realms of trade and investment. Even now, there's been some deepening of the non-security side of the relationshipbilateral trade set a new record in 2018 and many believe that U.S. officials want to signal that there can be more of that if the two sides are able to make progress on the Afghan peace and Pakistan 
counterterrorism issues that concern Washington the most right now. Also, the corona Pandemic created ripple for the whole world, also equally the U.S. engagements in Afghanistan as well.

FATF's challenge for Pakistan also took the new root after the Paris based terror financing watchdog extended Pakistan's deadline for meeting its mandatory 40-points. There is a bit of a disconnect here though, as Pakistan is keen to expand and broaden the relationship right away, seeking Washington help to get rid of grey listing of FATF. While the U.S. would rather keep the scope narrow for now until there's more progress on the issues that concern Washington the most, the alleged support of Pakistan to militants either haunt to India or continue to damage the peace process. All this said, the idea of pursuing a deep and strategic partnership between the U.S. and Pakistan sometime down the road is rather unlikely. First, there's just too much mistrust and baggage in the relationship. Second, strategic rivalry with China is the overarching theme in U.S. foreign policy and in its strategic calculations. China and Turkey are the only countries supporting Pakistan in FATF's move against Pakistan. It would be very difficult to craft a U.S. strategic partnership with a nation that is one of the closest allies of America's top strategic rival--a nation that the U.S. sees not only as a competitor, but as a threat. This is why the US-India strategic partnership, for all its challenges, has more potential. That partnership is driven, in great part, by a shared concern about China's rise and the troubling strategic implications for both the U.S. and India. The main issue is that America's retreat in the broader.

Muslim World \& Greater South Asia coincides with the peaceful rise of China and resurgence of Russia, so U.S. clout continues to diminish, hence, the U.S. is only one of three principal players -China, Russia \& US - no longer the 'sole superpower'. Right now, the talks with the Afghan Taliban are the centerpiece of the Pakistan-American foreign policy calculus, and Pakistan is pivotal to the Afghan peace process pushed by the Americans. Hence, the easing off of Washington's pressure on Pakistan which has given 'strategic space' for Pakistan to pursue its key foreign policy goals like Kashmir, CPEC and relations with India \& Iran (on all of which, Islamabad \& Washington don't see 'eye to eye') with greater confidence and more freedom to maneuver. In a post-American withdrawal from Afghanistan scenario, Washington is most likely to become antagonistic towards Islamabad on account of Pakistan's nuclear weapon programme and Islamabad's strategic partnership with China. India continued to pile up pressure on Pakistan when it comes to act against over 4, ooo suspects associated with militant organizations like Jaish-e-Muhammad (JeM) or Lashkar-e-Tayyaba (LeT) or Falah-i-Insaniat Foundation (FIF) (Siddiqa, 2011).

As already mentioned, bailing out the U.S. from its Afghan morass will not result in lasting U.S. goodwill for Pakistan. Any "rewards" will be made conditional on Pakistan accepting Indian hegemony, abandoning Kashmir and loosening ties with its only strategic partner, China. FATF has been another challenge for Pakistan and many believe to have it like a hanging sword on Islamabad where Pakistan is being molded the way American wanted to pursue peace process and get it done at all cost (Haqqani, 2013). The U.S. categorically told Pakistan to convince Taliban for the deal otherwise be ready for actions either coming in shape of FATF or Indian involvement in Pakistan affairs. It will also require avoiding any development of cooperation with Iran. As Kissinger said the price of American friendship is higher than the price of its enmity. Pakistan needs to develop as good a bilateral relationship with the U.S. as possible without seeking a strategic relationship with it which is out of reach and unaffordable. It must recognize that it cannot allow any development to weaken its strategic cooperation with China even if that greatly displeases the US and some quarters in Pakistan. On Kashmir, Pakistan must make clear that it will explore every opportunity for a peaceful resolution of differences with India no matter how long it takes. But it will never countenance Kashmiri genocide no matter what the price. This is the only way to avoid genocide in Kashmir and mutually suicidal war with India. There is no other way no 
matter what bleeding-heart liberals might pretend to the contrary. After the national betrayal of $1971 \mathrm{a}$ similar betrayal of Kashmir would set in process the end of Pakistan (Swami, 2006).

President Trump's approach towards Islamabad has ranged from outright hostility to its desire to stay engaged with Islamabad. Its ambivalence notwithstanding, it appears evident that the Trump's administration is pursuing an India centric policy towards South Asia in which goals of counterterrorism, promotion of peace and development, India centered notion of strategic stability and existing from Afghanistan with honor are key objectives. Washington under Trump has clearly spelled out its approach toward Pakistan which is a combination of carrot and stick. This was on display in Trump's 2019 (New Year) tweet in which he accused Islamabad for taking billions of dollars from the U.S. and failing to deliver on peace in Afghanistan. Washington also laid down condition-based markers for America's support for Pakistan. Trump has also used Washington's clout with the IMF to enable Islamabad receive IMF's bailout package. Washington has also used FATF sanctions as its main leverage to change Islamabad's strategic behavior. Washington is using both its carrot and stick policy to achieve its goals. Cut off of Coalition Support Funds and withholding of arms supplies are primary examples. FATF's tool was another additional diplomatic tool to pressurize Pakistan by putting embargo on different economic deals. Islamabad has caved in to the American pressure as well as its blandishments. Pakistan struggled to wipe out terror outfits as well as thousands of suspected militants either though many of them were being supported by the hostile organizations. So, for this purpose FATF after U.S. adopted this mantra for Pakistan asking it to fulfil its 40 toughest recommendations. They set a new deadline of June 2020, due to pandemic problems otherwise deadline expired in September last year.

With an alarming tweet on January 1, 2019, the U.S. President Donald Trump almost cut off all ties with Islamabad pointing out that Pakistan continued to make fool Pentagon and White House since decades. Enough is enough, Trump said, Washington needed to review its policy towards South Asia. Before this, President Trump laid out his government's policy for South Asia in August 2017, observing "Pakistan must either 'do more' to have control on militants." Since Donald Trump became the 45th President of the U.S. in 2016 Presidential elections as a Republican candidate (Cohen, 2016), and took the charge of office on January 20, 2017, he made a telephonic conversation with the then Prime Minister Nawaz Sharif on November 30, which later gave rise to many speculations. In this conversation Donald assured the Prime Minister, "I am ready and willing to play any role that you want me to play to address and find solutions to the outstanding problems". On April 27, Trump gave an address at the center for national interest, at Washington DC based think-tank. In this speech, he raised objection on U.S. foreign policy in the post - cold war era and argued that the policy of that era was wasteful, unreliable and ineffective. But this time American foreign policy would mainly focus on rebuilding America's military and economic stability. For this purpose, they would spread radical Islam and fashioning what he called "a new rational American foreign Policy". Being a businessman, Trump knows that how the peace and stability is important for the growth of economy and trade. In July 2017, President Trump claimed, "Pakistan often gives safe heaven to agents of chaos, violence and terror." On New Year's Day in 2018, again Trump gave remarks in his tweet that the US has "foolishly given Pakistan more than 33 billion dollars in aid over the last 15 years, with little in return, promising no more". He claimed that Pakistan is not playing his role against the terrorism, rather Pakistan is supporting these terrorist groups (Afzal, 2018).

In response to this, the then Foreign Minister of Pakistan Khawaja Asif had said that Mr. Trump was likely "disappointed at the US defeat in Afghanistan and that was the only reason he was flinging accusations at Pakistan". We have already told the US that we would not do more, so Trump holds no any importance." Pakistan has already made countless sacrifices in the war against terror. Thousands of 
Pakistani soldiers, police, intelligence professionals and also dozens of civilians have died in fighting against militant groups. On July 23,2019 Donald Trump held his face- to- face talks with the Pakistani Prime Minister Imran Khan during khan's trip to Washington DC. Being a businessman, trump knows that for economic prosperity regional peace is an essential prospect. Therefore, the purpose of this meeting was to mend relations and conflicts to be solved based on Afghanistan Taliban issue. Khan's gave his remarks about speaking at the United States Institute of Peace (USIP) with Trump as "one of the most pleasant surprises”. In this meeting Imran Khan explained Pakistan's role in helping United States while bringing security in the region by giving countless sacrifices in counterterrorism operations. Trump also showed his wishes with the withdrawal of troops from Afghanistan to cut down on United States entanglement in global affairs. Trump said that Pakistan is helping in the US to" extricate "its troops from Afghanistan, through political negotiations. Trump said that we could win war against Taliban within 10 days but we don't want to kill millions of innocent people. Therefore, he expects from Imran Khan that he would play his role to pressure the Taliban into striking a peace deal with the Afghan government. Imran Khan also exclaimed that I am happy with this meeting with trump because we both have mutual goals that are to bring peace in Afghanistan. Moreover, after one week of this meeting on July 27, the United States gave approval of \$125 million in technical and logistics support for Pakistan F-16 fighter jets. Donald Trump also offered to mediate in the conflict of Kashmir between India and Pakistan at the White House meeting.

Washington has used a mix of tactics to try to achieve its goals in Pakistan (Hussain, 2016). These have included carrots and sticks. Aid (both financial and military) has been one of the top carrots. The unstated idea has been to use aid as a leverage point: In effect, we're providing you with guns and money, and now you should help us out by going harder after the terrorists. When the U.S. has concluded that the carrots aren't working, it has resorted to sticks, such as cutting off security assistance after Pakistan's nuclear weapons tests and more recently after Trump concluded Pakistan wasn't doing enough on counterterrorism. The idea from the U.S. perspective is that Pakistan, recognizing the importance of the aid it's not getting, will act on U.S. demands in order to have that aid reinstated. What is often forgotten by U.S. policymakers is that every country has its own interests, and these interests of other countries often won't align with Washington's. And despite US efforts to conciliate, cajole, or pressure, those countries won't necessarily adjust their interests just because Washington is trying to get them to do so. Every country follows its own interests (Shah, 2007). The U.S. now regards major power competition as its primary concern. It has adopted Indo-Pacific strategy to pursue its interests in Asia. The U.S. is likely to work with Pakistan within the context of its global strategy. Washington seeks to secure these goals by trying to leverage its influence on Pakistan through 3 avenues: a) bilaterally, dangling the carrot of military aid \& economic investment; using multilateral fora like IMF \& FATF to maintain pressure on Pakistan; using 'good offices' of its close Arab allies like Saudi Arabia \& UAE to influence Pakistan. Pakistan has now become quite experienced and used to this American game of 'snakes \& ladders', so it also knows how to handle the U.S. deftly without conceding on its core interests (Taliaferro, 2001).

\section{Resetting Terms of Engagement in Afghanistan}

Afghan government talks are directly related to Pak-U.S. relations and the calculations that go into those relations. That is very clear. The main reason why US-Pakistan relations have improved so much over the last year or so-and a core reason why Imran Khan was invited to Washington this past summer-is because the US views Pakistan not just as a key partner in the Afghan reconciliation process, but as an essential partner in that process. President Trump's immediate aim was to obtain the support of Pakistan in bringing the Taliban to the negotiating table so that a deal between them and the Kabul regime could be reached that would allow US troops to withdraw from Afghanistan which would be 
presented as a historic achievement for Trump's election campaign. The US prefers an Indian presence in Afghanistan even if it needs Pakistan's assistance. China does not want to see Indian influence in Afghanistan. Ultimately, it must be for a nationally acceptable Kabul government to decide. But Pakistan can no longer hunt with the hounds and run with the hare in Afghanistan (Chaudhry, 2018).

The situation has been complicated by Trump's pulling the plug on the agreement with the Taliban, the useless outcome of the Afghan elections which will delay the formation of a new Afghan coalition, the rise of ISIS-Khorasan group in Afghanistan, the mistrust of both Kabul and the Taliban towards Pakistan and uncertainty about what role Pakistan can play in Afghanistan under current circumstances. At the regional level, the US wishes to work with Pakistan to secure peace in Afghanistan. The U.S. also wants to develop stronger commercial and investment ties with Pakistan, says Pakistan former Ambassador to U.S. Aizaz Chaudhry. "The focus in recent years has been to find ways for Pakistan and the U.S. to work together for peace and reconciliation in Afghanistan. The U.S. has recently engaged in direct talks with Taliban. This kindled a ray of hope for peace in Afghanistan. However, there are still a number of requirements for peace to prevail in Afghanistan. It is important to simultaneously facilitate Intra-Afghan dialogue. This process has started. All major and regional powers must support the intra-Afghan dialogue. Further, the U.S. can and must play a role in defusing tensions in South Asia, and prevail upon the Indian government to stop gross human rights violations and atrocities against the people of Indian occupied Kashmir. No country stands to gain more from peace in Afghanistan than Pakistan. Pakistan, therefore, has been facilitating peace efforts, which have been widely appreciated including by the United States. It is important that Pakistan continues its efforts to facilitate peace in Afghanistan. Peace in Afghanistan can unleash enormous opportunities for regional connectivity and economic development. Pakistan has suffered the most from the crisis in Afghanistan. We, therefore, are convinced that a peaceful Afghanistan would best serve the interests of the region. Pakistan has supported the US-Taliban talks and would continue to facilitate the peace process including intra-Afghan dialogue. One of the primary reasons why Washington wants to remain engaged with Islamabad is its calculation that without Islamabad's help Washington cannot leave Afghanistan with honor. This imperative has created a convergence of interests between Islamabad and Washington," observed former Pakistan Ambassador.

\section{Pakistan, United States and FATF}

The FATF set toughest conditions for Pakistan and many believe that its all happening on behest of superpowers like France, Germany, UK and U.S. Islamabad has always sought strong strategic relations with great power in order to counterbalance the threat from its arch-rival India. However, Pakistan keeps strong relations with the United States during Cold war but later on these relations have been facing volatile situations. This road remains bumpier after Washington used FATF as a new sword for Pakistan using as a tool for economic sanctions as well. But after the end of the Cold War U.S. priorities changed which led to straining of relations between the two (Cohen, 2004). Nonetheless, the event of 9/11 led to reengagement of strategic realties between United States and Pakistan on global war against terrorism in Afghanistan. But after short period of time both the sides developed differences over the issue of terrorism especially in Afghanistan. Trump administration national security strategy 2017, also declared that the main focus of U.S national security would be at the strategic competition with the great power especially China and Russia. It also declared that terrorism would be secondary issue in US national security strategy. Pakistan-US relations are facing many challenges in current geo-strategic environment. First, drifting of Pak-US goals in Afghanistan. Second, Pakistan alleges support to Afghan Taliban. Third, Pakistan increasing defense cooperation with the China including China's flag mark project "Pakistan China Economic Corridor.” Finally, the U.S. policy 
is to enhance strategic relations with India in the long run. Drifting of Pak-US goals in Afghanistan (Kaura, \& Era, 2017).

The United States is fighting a longest war in its history in Afghanistan (Dalpino, C. (2017). Past five years have been hectic for Pakistan. FATF put Pakistan into its grey list for the first time eight years back but Islamabad gave political commitment and graded up. But again FATF put Pakistan on its watch list in 2018. Since June 2018, Pakistan has been under pressure either from FATF's permanent member countries or from U.S. However, Pakistan under FATF's sword played primary role in ousting of Taliban from Afghanistan but with the passage of time Pakistan and United States developed differences regarding the end goals in Afghanistan. The main bone of contention between the two was increasing role of India in Afghanistan. While Pakistan allege that U.S. is giving leverages to India to enhance its role in internal affairs of Afghanistan. Moreover, Pakistan also emphasized the Pukhtun populations should be given due to power share with the Afghan government. In the current scenario, Pakistan position in Afghanistan is more aligned with the Russia, China and Iran rather than U.S. Currently, Pakistan is playing its role for the final settlement of Afghanistan. However, if Pakistan failed in persuading Afghan Taliban to find end solution of Afghan conflict then such situation would have negative implication for Pakistan security. Moreover, Pakistan foreign policy objective in Afghanistan are to secure Pak friendly regime and to minimize the role of India.

\section{Conclusion}

Although it is not clear yet, what would be new shape of FATF's challenge for Pakistan, many, however, believe that June 2020, the new set deadline, could see a positive environment for Islamabad. Reasons are multiple, one most important is Pakistan's sincere efforts to cope with terror financing and money laundering in the country. Pakistan gave a strong political commitment to FATF by fulfilling 13 key plans of Paris based terror financing watchdog. This commitment shows that Islamabad would be able to convince FATF and its members to get out of grey list. Many experts believe that Pakistan would manage to get the desired results in response to its hard work in FATF October 2020 meet up. But threat, however, has not over yet, according to many experts, Pakistan must show more commitment to meet all 40 key recommendations of FATF which is ranging from improving its banking system to put check on militants associated with different 78 banned organizations. So, the coming months are though bumpy for Pakistan either its relations with U.S. or FATF, but consistent efforts could help the state to get out of this terror financing dilemma.

\section{References}

Afzal, M. (2018). Pakistan under siege: Extremism, society, and the state. Brookings Institution Press.

Chaudhry, G. M. (2018). Historical Perspective of Pakistan-Us Relations and the USA's Afghanistan and South Asia Strategy: Implications for National Security Of Pakistan With Policy Options To Maintain Strategic Balance In South Asia. Journal of the Research Society of Pakistan, 55(2).

Cohen, S. P. (2004). The idea of Pakistan. Brookings Institution Press.

Cohen, S. P. (2016). The South Asia Papers: A Critical Anthology of Writings by Stephen Philip Cohen. Brookings Institution Press.

Dalpino, C. (2017). US security relations with Southeast Asia in the Trump administration. Contemporary Southeast Asia, 39(1), 3-8.

George, K, V. "Starting to develop much better relationship with Pakistan: Trump," The Hindu, 14 October 2017.

Haqqani, H. (2013). Pakistan, the United States and an Epic History of Misunderstanding: The Magnificent Delusions. New York: Published Public Affairs in the US, 30. 
Hussain, Munawar. (2016). Pak-US Relations: An Historical Overview. Pakistan Journal of History and Culture. XXXVII (2)

Kaura, V., \& Era, T. (2017). US-Pakistan relations in the Trump era: Resetting the terms of engagement in Afghanistan. ORF Occasional Paper, (128).

Kaura, V., \& Era, T. (2017). US-Pakistan relations in the Trump era: Resetting the terms of engagement in Afghanistan. ORF Occasional Paper, (128).

Kunwar Khuldune Shahid, India dominates talks as Tillerson stops over in Pakistan, Asia Times, 27th October 2017.

PTI, “Donald Trump ready for any steps if Pakistan doesn't mend its ways: Jim Mattis,” Economic Times, 5 October 2017, http://economictimes.indiatimes.com/news/defence/donald-trump-ready-forany-steps-if-pakistan-doesnt-mend-itsways-jim-mattis/articleshow/60951178.cms.

Shah, S. M. A. (2007). Pakistan and the War against Terrorism. Pakistan Horizon, 6o(2), 85-107.

Siddiqa, A. (2011). Pakistan's counterterrorism strategy: Separating friends from enemies. The Washington Quarterly, 34(1), 149-162. https://www.tandfonline.com/doi/abs/10.1080/016366oX.2011.538362?journalCode=rwaq20

Swami, P. (2006). India, Pakistan and the Secret Jihad: The Covert War in Kashmir, 1947-2004. Routledge.

http://www.sanipanhwar.com/India\%2oPakistan\%20and\%2othe\%2oSecret\%2oJihad\%2oThe\%2oCov ert\%2oWar\%2oin\%2oKashmir,\%201947\%E2\%80\%932004.pdf

Taliaferro, J. W. (2001). Security seeking under anarchy: Defensive realism revisited. International security, 25(3), 128-161.

Tillerson's stopover, (Editorial), Dawn, 26 October 2017

Yusuf, M. (2017). A Marriage Estranged: The Strategic Disconnect between Pakistan and the United States. Asia Policy, 24(1), 46-52.https://muse.jhu.edu/article/666576/summary 